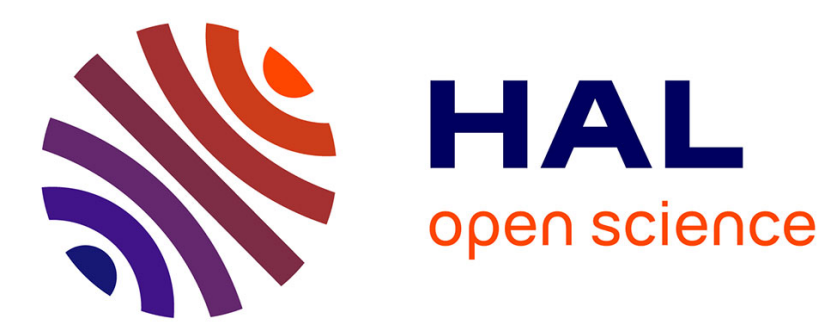

\title{
Global OA APCs (APC) 2010-2017: Major Trends
}

\author{
Heather Morrison
}

\section{To cite this version:}

Heather Morrison. Global OA APCs (APC) 2010-2017: Major Trends. ELPUB 2018, Jun 2018,

Toronto, Canada. 10.4000/proceedings.elpub.2018.16 . hal-01816699

\section{HAL Id: hal-01816699 \\ https://hal.science/hal-01816699}

Submitted on 15 Jun 2018

HAL is a multi-disciplinary open access archive for the deposit and dissemination of scientific research documents, whether they are published or not. The documents may come from teaching and research institutions in France or abroad, or from public or private research centers.
L'archive ouverte pluridisciplinaire HAL, est destinée au dépôt et à la diffusion de documents scientifiques de niveau recherche, publiés ou non, émanant des établissements d'enseignement et de recherche français ou étrangers, des laboratoires publics ou privés.

\section{(이) $\$$}

Distributed under a Creative Commons Attribution - NonCommercial - NoDerivatives $\mid 4.0$ 


\title{
Global OA APCs (APC) 2010-2017: Major Trends
}

\author{
Heather Morrison
}

This study is one of the sub-projects of the multi-year Sustaining the Knowledge Commons study on the economics of transition to OA scholarship, funded by Canada's Social Sciences and Humanities Research Council, through an Insight Grant.

\section{Introduction}

1 Sustainable OA (OA) scholarly journal publishing requires a shift from demand to supply side economics. There are many approaches to supply-side funding, including sponsorship, library journal hosting, cooperatives, and transitioning library subscriptions funds to OA support (offsetting in interim phase). The APC model is used by a minority of fully OA journals. APC is important to study as a model that is working well for some journals, as a model some advocate as the basis for systemic change, and as one surrogate for necessary average cost per article, useful to assess the cost-efficiency of diverse approaches.

2 This is the 2017 edition of a longitudinal study (Morrison et al., 2014-, 2015, 2017) to observe trends in OA journal publishing over time with a focus on APCs and fully-OA journals, to provide evidence on which to base decisions on support for supply-side economics. Will the APC market continue existing market trends in subscriptions of consolidation and price rises beyond inflation? If so, this would be a reason to consider other models. Or perhaps APCs will introduce competition into the marketplace by making the cost of publication transparent to authors and payers. If so, this would be a reason to support APCs.

3 The literature in the field is extensive. This section is limited to recent exemplars of major research approaches in order to provide context for this paper.

4 One approach involves payers monitoring their APC payments. Universities UK (2017) recently released a major report, Monitoring the transition to Open Access: December 2017. 
This is an exceptionally comprehensive report on activity in a country that has pioneered a systemic approach to OA transition. Two findings of key relevance to this study:

1. "mean average APC payment rose from $£ 1,699$ in 2013 to $£ 1,969$ in 2016 , a rise of $16 \%$ (as compared with a rise of $5 \%$ in the CPI)." (P. 39), (hybrid journals: $£ 2,095$; fully-OA journals $£ 1,640$ ). These figures are reported as being in line with other UK and German-based APC payers; and

2. more than half of APC expenditures went to the 3 largest publishers, Elsevier, Springer Nature, and Wiley. OpenAPC (n.d.) is a project in which participating institutions submit data on their APC payments in standard format permitting for re-combining of the results.

5 There is significant overlap as 51 of the 117 participants are from the UK. The average APC paid for the 44,373 articles published in fully and hybrid OA journals was $€ 1,936$ and the median was $€ 1,756$.

6 Other researchers study cost analysis of the potential for systemic transition. Schimmer, Geschuhn, \& Vogler (2015) developed an approach of transitioning traditional journals from subscriptions to OA using offsetting for the OA2020 initiative. As of December 2017, 95 institutions had signed an Expression of Interest to pursue this approach. The Mellon Foundation (2016) Pay it Forward project, similarly assuming transition of existing publishers, found that for the most research-intensive North American research institutions, the total cost to publish in a full APC market would exceed existing library budgets. My (Morrison, 2013) analysis of the potential for a global flip to OA journal publishing provides evidence that there is more than sufficient funding from existing spend by academic libraries, and significant cost savings would be possible, but that this requires additional transition such as support for new OA publishers and/or support for small not-for-profit journals.

7 The objectives of this study are to determine the average and variability of global APC in 2017, and to compare OA journal publishers in 2014 and 2017 to assess what impact, if any, the UK, OA2020, and other initiatives to support APC payment have had on the market to date.

\section{Method}

8 A full description of the 2016 version of the main dataset, henceforth referred to as OA Main used in this project is described in full in Data (Morrison et al., 2017). This remixed dataset includes our team's collection of data from publisher websites, extensive metadata from DOAJ, and the entire datasets for 2010 from Solomon \& Björk (2012) and for 2015 and 2016 from Crawford (2017). Versions of the dataset itself are available for download from the project's dataverse (Morrison et al., 2014-). 2017 additions include extensive APC information from publisher lists and merger of almost the entire 2017 and 2018 (Jan. 31 each year) DOAJ metadata set. Columns have been added in 2017 for date of data collection and provenance of data (e.g. specific publishers' website, DOAJ). Data analysis focuses on 2017, with occasional use of 2018 data (DOAJ and publisher websites) for clarification and updates. The 2014-2017 publisher comparison relies on a full copy of DOAJ metadata from 2014 that is not included in OA main. 


\section{Results}

\section{Journals by status}

\begin{tabular}{|l|l|l|}
\hline Category & \# of journals & $\%$ of 2017 sample \\
\hline No publication fee & 7,428 & $53 \%$ \\
\hline Publication fee confirmed & 3,795 & $27 \%$ \\
\hline No information on publication fee & 2,250 & $16 \%$ \\
\hline Journal ceased or title not found & 612 & $4 \%$ \\
\hline Not open access & 1 & $0 \%$ \\
\hline 2017 sample grand total & 14,086 & $100 \%$ \\
\hline
\end{tabular}

914,086 journals are included in the 2017 sample. "No publication fee" indicates journals where information on publisher's website clearly indicates that there is no fee, "No" is indicated in the DOAJ 2017 column "Journal article processing charges (APCs)", or Crawford has indicated that the journal is free. Publication fee confirmed means that there is a publication fee listed on the publisher's website (types of fees and amounts are covered below), or that "Yes" in indicated in the DOAJ 2017 column "Journal article processing charges (APCs)". "No information on publication fee" means that no information indicating whether or not there is a publication fee could be found on the publisher's website, or the DOAJ 2017 column "Journal article processing charges (APCs)" indicates "No information". Journals that are ceased are clearly indicated as no longer published on the publisher's website. "Title not found" might a ceased publication, technical error, change in publisher, etc. Only 1 journal was found to have changed from open access to subscription status; this is indicated as a percentage of $0 \%$ due to rounding error.

Number of journals by type of publication fee model

\begin{tabular}{|l|l|}
\hline Publication fee model & \# journals \\
\hline APC (per-article fee) with amount including 0 & 3,625 \\
\hline APPC (per-page fee) & 81 \\
\hline Cost not specified (website refers to publication fee, no amount given) & 61 \\
\hline Pay what you want (Cogent; not used in 2018) & 15 \\
\hline Charge per word & 6 \\
\hline Conflicting information (e.g different amounts given on different webpages) & 4 \\
\hline
\end{tabular}




\begin{tabular}{|l|l|}
\hline Page charges (new 2018; per-page fee clearly linked exclusively to print) & 3 \\
\hline Publication fees confirmed total & $\mathbf{3 , 7 9 5}$ \\
\hline
\end{tabular}

Not all publication fees are APCs; there are many different sub-models. In this study, fees are treated differently if they are charged per article, per page, or per word (new in 2017). The pay what you want model was used by Cogent in 2017 and is not listed in 2018. The category of page charges has been added in 2018 and is used where the journal only charges a per-page fee clearly related to the print version of the journal. This category may be underestimated because many journals are published in print as well as electronically; hybrid fee structures (APC + print-based charges such as colour and image charges) are not unusual. Submission fees and other types of sub-models such as differential pricing by article type, length, origin of author, etc., are not included.

11 The following tables analyze 3,231 journals for which there is an amount for APC other than 0 (free-for-now journals) and 81 journals with an amount for APPC other than 0 . Excluded are a few journals using different models (e.g. charge per word, page charges clearly exclusively print-based, 15 Cogent journals were using a "pay what you want" approach in 2017), and 61 titles that have a cost, but the amount is not specified on the publisher's website.

2017 APC (per article) and APPC (per page) in USD

\begin{tabular}{|l|l|l|l|}
\hline APC amount & \# journals & APPC amount & \# journals \\
\hline $0-1,000$ & 1,895 & $0-100$ & 71 \\
\hline $1,000-2,000$ & 1,011 & $100-200$ & 7 \\
\hline $2,000-3,000$ & 222 & $200-300$ & 1 \\
\hline $3,000-4,000$ & 97 & $300-400$ & 1 \\
\hline $4,000-5,000$ & 6 & $>400$ & 1 \\
\hline Total \# journals & 3,231 & & 81 \\
\hline
\end{tabular}

12 The table above presents the 2017 APC (per-article) and APPC (per-page) in USD by frequency in thousands, excluding APC/APPC of 0 (free for now journals). Both APC and APPC exhibit a skew towards the low end of the price range. For example, 1,895 journals have APCs of 1,000 USD or less, while only 6 have APCs above 4,000. 


\section{APC in USD (excluding 0)}

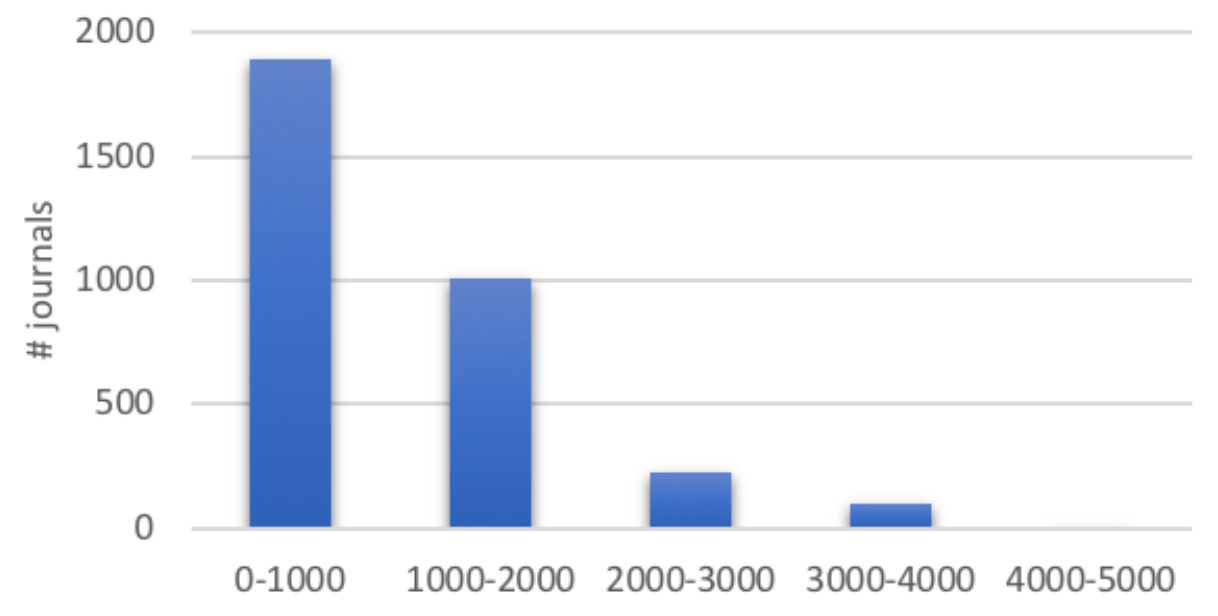

13 The above chart illustrates the skew in pricing toward the low end of the range. There are many more journals with prices below 1,000 USD than there are at the high end of the price range.

2017 APC (per article) and APPC (per page) in USD: range, central tendencies and standard deviation

\begin{tabular}{|l|l|l|}
\hline & APC & APPC \\
\hline Average & 974 & 77 \\
\hline Mode & 1,780 & 86 \\
\hline Median & 750 & 79 \\
\hline Standard Deviation & 832 & 62 \\
\hline
\end{tabular}

14 This table demonstrates considerable variation in pricing. The range is wide; APC ranges from 1-5,000 USD, APPC from 4-400 USD. Differences between the 3 measures of central tendency are particularly marked for APC. The median or mid-point of 750 USD is $23 \%$ lower than the average, that is, more than half of APC charging journals have fees substantially below the average, while the mode or most common APC of 1,780 USD is close to double the average. For both APC and APPC the standard deviation, a measure of variability, is high, not much lower than the average. 
APC: direction of change 2017-2016

\begin{tabular}{|l|l|l|l|l|}
\hline & \multicolumn{2}{|l|}{$\begin{array}{l}2017 \text { data from publisher's } \\
\text { website }\end{array}$} & $\begin{array}{l}2017 \text { data from DOAJ } \\
2017\end{array}$ \\
\hline Price decrease & 133 & $6 \%$ & 415 & $63 \%$ \\
\hline No change & 1,091 & $46 \%$ & 31 & $5 \%$ \\
\hline Price increase & 1,160 & $49 \%$ & 215 & $33 \%$ \\
\hline Total & 2,384 & $100 \%$ & 661 & $100 \%$ \\
\hline
\end{tabular}

The table above illustrates that the overall direction of price changes (same, decrease or increase) varies with the source of data used for the 2017 APC. When data is gathered directly from the publisher's website, $49 \%$ of journals show a price increase from 2016 to 2017; from DOAJ, the percentage is $33 \%$. The difference is most marked for price decrease, with only $6 \%$ of journal prices on publisher websites showing a decrease but $63 \%$ of prices listed in DOAJ. Note that the list of journals included with pricing from the publisher's website includes titles that were not in DOAJ as of 2017 (deleted or not yet added). Both sets of data are included separately to illustrate that the overall direction of price changes is dependent on the sample of journals included. 61 APPC journals for which data is available for 2016 and 2017 (all derived from publishers' websites), show a similar trend, 5 (8\%) of journals have decreased in price, 33 (54\%) show no change and $23(38 \%)$ have increased in price.

\section{Publisher Trends}

\section{No publication fee: publisher type}

16 A rough analysis of the 7,428 journals with "no publication fee" was conducted as follows. First, journals with a society or institutional association were found using a search/ eliminate/search approach. 2,705 journals were found to have an entry in DOAJ 2017 for "society or institution". An additional 204 journals had a "society or institution" entry in DOAJ 2018 but not DOAJ 2017. 146 journals were identified as having a not-for-profit society, university, or government partnership or full partner through the work of our team. Of the remaining titles, 1,169 publisher names begin with some variation of "university". 103 titles begin with some variation of "society". The remaining titles were searched for words or partial words drawn from the sample relating to university (universid, university, college, colégio, college, department, escola, escula, faculda, faculty); society (socied, societ, sociét, association, asociación, associação), government (government, minist) or words that might fit more than one category (academy, institut). A total of 7,367 titles were found to have a not-for-profit society, university, or government publisher involved, approximately $99 \%$ of the sample of 7,428 "no publication fee" journals. A word search of the full list of no publication fee titles for universid and universit found a total of 3,452 titles. That is, about $46 \%$ of the no publication fee journals have a fairly clear university publishing model; this percentage is 
likely understated as words suggesting a sub-university publisher (faculty, school, department) were not included.

A complete set of DOAJ metadata from 2014 (9,665 journals) and active titles in OA main 2017 (combining DOAJ metadata with publisher website data) were used for this comparison. Pivot table reports were developed for the list of publisher names. These reports were then examined and further collated manually as publishers are not always automatically collated, primarily due to small variations in publisher names and separate listings by imprint (e.g. Springer, BioMedCentral, and Nature).

The very long tail

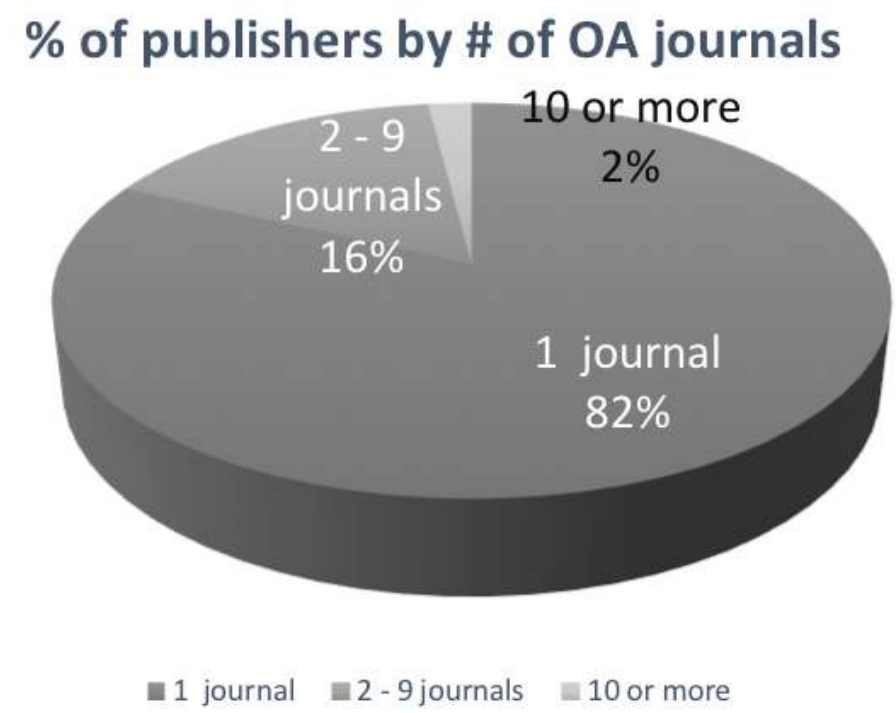

As illustrated in the above chart, the vast majority of open access publishers studied are very small. Only $2 \%$ publish 10 or more OA journals; $16 \%$ publish $2-9$ journals, and $82 \%$ publish only one journal. The distribution is almost identical for 2014, except that the percentage of publishers with just one journal rounds up to $84 \%$ (without changing the other percentages due to rounding errors).

Number of publishers by \# of OA journals 2014-2017

\begin{tabular}{|l|l|l|l|l|}
\hline Publishers by number of OA journals & DOAJ 2014 & $\begin{array}{l}\text { OA Main } \\
2017\end{array}$ & change \# & change\% \\
\hline Total & 5,326 & 6,329 & 1,003 & $19 \%$ \\
\hline 1 journal \# & 4,497 & 5,216 & 719 & $16 \%$ \\
\hline 1 journal\% & $84 \%$ & $82 \%$ & & \\
\hline$<10$ journals \# & 5,228 & 6,197 & 969 & $19 \%$ \\
\hline$<10 \%$ & $98 \%$ & $98 \%$ & & \\
\hline 10 or more $\%$ & $2 \%$ & $2 \%$ & & \\
\hline
\end{tabular}


The above table presents a breakdown of the very long tail. More than $80 \%$ of OA journal publishers publish only one journal; 98\% publish fewer than 10 journals, and only $2 \%$ publish 10 or more journals. These percentages are almost identical for 2014 and 2017. This table also illustrates that there is a net total of about 1,000 new publishers added to DOAJ since 2014.

In contrast with the number of publishers by publisher size, there is a relative decrease in the number of journals published by smaller publishers in 2017 (47\% of journals were one-off in 2014, 37\% in 2017). This finding may be an anomaly reflecting the different sampling methods in 2014 and 2017.

25 top ranked publishers in 2017 by number of journals

\begin{tabular}{|c|c|c|c|}
\hline Rank & Publisher & \begin{tabular}{ll|}
$\#$ & journals \\
2017 &
\end{tabular} & $\begin{array}{l}\# \text { of journals DOAJ } \\
2014\end{array}$ \\
\hline 1 & $\begin{array}{l}\text { Springer }(222)+\text { BioMedCentral }(306)+\text { Nature } \\
(86)\end{array}$ & 614 & 341 \\
\hline 2 & De Gruyter Open & 454 & 2 \\
\hline 3 & Elsevier & 415 & 8 \\
\hline 4 & Wolters Kluwer Medknow & 378 & 97 \\
\hline 5 & Hindawi Publishing Corporation & 294 & 444 \\
\hline 6 & Scientific Research Publishing & 246 & 125 \\
\hline 7 & MDPI AG & 186 & 104 \\
\hline 8 & SAGE Publications & 156 & 10 \\
\hline 9 & Taylor \& Francis Group & 152 & 2 \\
\hline 10 & Dove Medical Press & 129 & 96 \\
\hline 11 & Wiley & 86 & 13 \\
\hline 12 & Universitas Negeri Semarang & 66 & 3 \\
\hline 13 & Bentham Open & 65 & 104 \\
\hline 14 & Copernicus Publications & 55 & 37 \\
\hline 14 & Frontiers Media S.A. & 55 & 30 \\
\hline 15 & Macrothink Institute & 52 & 8 \\
\hline 15 & PAGEPress Publications & 52 & 48 \\
\hline 15 & Universidade de São Paulo & 52 & 36 \\
\hline
\end{tabular}




\begin{tabular}{|l|l|l|l|}
\hline 16 & SCIENCEDOMAIN International & 50 & 15 \\
\hline 17 & Internet Scientific Publications, LLC & 47 & 47 \\
\hline 18 & Ubiquity Press & 45 & 10 \\
\hline 19 & Oxford University Press & 44 & 11 \\
\hline 20 & Baishideng Publishing Group Co. Limited & 43 & 14 \\
\hline 20 & Canadian Center of Science and Education & 43 & 37 \\
\hline 21 & Universitas Udayana & 40 & N/A \\
\hline
\end{tabular}

The table on the previous page presents the top 25 publishers for the 2017 dataset by number of journals included, the ranking and the number of journals included in $2017 \mathrm{OA}$ main and the 2014 DOAJ. This illustrates the growth of the OA journal portfolios of some traditional publishers in the last 3 years. In 2014, DOAJ included 2 De Gruyter titles; today according to the De Gruyter Open website this publisher lists over 400. DOAJ listed 8 Elsevier titles in 2014; the Elsevier website in 2017 listed 415 fully OA journals. 5 of the largest publishers are no longer listed in DOAJ (Canadian Center of Science and Education, Internet Scientific Publications, LLC, Macrothink Institute, SCIENCEDOMAIN International, and Scientific Research Publishing; Bentham Open is listed in DOAJ in 2017, but not 2018). 4 of the largest publishers are universities.

\section{Discussion}

The global average APC for 2017 was 974 USD, almost identical to the global average of 964 USD reported from our 2014 survey (Morrison et al., 2015) and not much higher than the 2010906 USD average reported by Solomon and Björk (2012). These findings contrast with the findings of Universities UK of a $16 \%$ increase in approximately the same time frame. The global average is less than half the reported average of $£ 1,640$ (approximately 2,300 USD) paid for APCs reported by Universities UK (2017) and the $€ 1,936$ reported by OpenAPC participants (approximately 2,400 USD). Factors that may account for this are the difference in value of currency between countries; APCs of developing world publishers are relatively low when translated into USD, and the UK's approach of providing block grants specifically to support APCs has probably had an impact on publishers of UK research. However, the case UK-based Ubiquity Press (n.d.), founded by University College London in 2012, demonstrates the potential for cost-savings. Ubiquity's base APC of $£ 400$, covering professional publishing services, is $24 \%$ of the average UK APC 2016 spend of $£ 1,640$ for fully-OA journals as reported by Universities UK (2017).

There is a wide range in pricing and considerable variability. The direction of change in pricing for APCs from 2016 to 2017 also varies, showing prices that are the same, have decreased or increased. Pricing on publisher websites has tended to remain the same or increase, while pricing based on DOAJ shows a greater tendency to decrease prices. This data suggests that the volatility of this emerging market that as first described in 2014 
(Morrison et al., 2015) is still prevalent. New publishers and journals are entering the market. Initial pricing may be experimental in nature, or artificially low in the case of new journals in order to attract content.

There has been noticeable growth in the OA journal portfolios of large traditional publishers. One factor in this growth is acquisitions. The Springer-BioMedCentral, Wolters Kluwer-Medknow, and De Gruyter-Versita acquisitions all predate 2014. In 2016, Springer acquired Nature. In 2017, Taylor \& Francis acquired Co-Action and Sage acquired Libertas Academica. Another factor is partnerships with societies and/or universities; this approach is evident in the OA title lists of De Gruyter, Elsevier, and Wolters Kluwer Medknow. As a result, many of their OA titles do not have APCs.

This slight tendency toward market concentration in the hands of the largest publishers is outshadowed by the very long tail of small publishers and the extensive involvement of university and society publishers as demonstrated by a very rough analysis suggesting that approximately $99 \%$ of the 7,428 journals that do not have publication fees have publisher names that include some variation of words closely related to university (e.g. university, universidad) or society (e.g. society, sociedad). This data suggests that the sponsorship model, with costs paid for by the sponsoring university or society, may be more prevalent than APC. This merits further study.

Limitations: the number of fully OA journals being published today is not known and would be very difficult to ascertain in the short term due to rapid growth. Publishers that have never been included in DOAJ are not reflected in this study; this will include publishers who have not met the criteria for DOAJ, and publishers who have not applied for inclusion in DOAJ. In order to track pricing trends over time, the full lists of journals by large publishers are included while the lists of smaller publishers are limited to titles in DOAJ. The data for this study are drawn from several sources using slightly different methodology.

\section{Conclusion}

The evidence to date is inconclusive, which suggests that those who pay for scholarly publishing (universities, libraries, funding agencies) have some ability to influence the outcome. Block payment for APCs in the UK appears to support pricing more than four times what is needed for professional UK-based scholarly OA journal publishing.

The very long tail of many very small OA journal publishers, many produced by universities, societies, and independent academics, suggests that a sponsorship model may be more prevalent than APCs and this approach merits further research. Many notfor-profit journals do not charge APCs. Providing modest support for such journals might be the most efficient way to achieve cost savings in the transition to open access, and at the same time avoid perceptions of low quality OA journal publishing associated with commercial APC that are not listed in DOAJ. 


\section{BIBLIOGRAPHY}

\section{References}

Crawford, W. (2017). Gold OA journals 2011-2016. Project page (includes links to data and books). Retrieved December 20, 2017 from https://waltcrawford.name/goaj.html

Mellon Foundation (2016). Pay it forward: investigating a sustainable model of OA article processing charge for large North American research institutions. University of California Libraries. Retrieved Dec. 20, 2017 from http://icis.ucdavis.edu/?page_id=713

Morrison, H. (2013). “Economics of scholarly communication in transition.” First Monday. http:// dx.doi.org/10.5210/fm.v18i6.4370

Morrison, H. (2014-). OA APC dataverse. Retrieved Dec. 21, 2017 from https:// dataverse.scholarsportal.info/dataverse/oaapc

Morrison, H., Brutus, W., Dumais-Desrosiers, M., Kakou, T. L., Laprade, K., Merhi, S., Ouerghi, A., Salhab, J., Volkanova, V., Wheatley, S. (2017). "OA APCs (OA APC) Longitudinal Study 2016 Dataset.” Data. 2(2): 13. doi:10.3390/data2020013

Morrison, H., Salhab, J., Calvé-Genest, A., Horava, T. (2015). “Open Access Article Processing Charges: DOAJ Survey May 2014.” Publications 2015; 3: 1-16.

OpenAPC (n.d.). OpenAPC project page. Retrieved December 20, 2017 from https://treemaps.intactproject.org/

Schimmer, R., Geschuhn, K. K., \& Vogler, A. (2015). Disrupting the subscription journals' business model for the necessary large-scale transformation to OA. A Max Planck Digital Library OA White Paper. München, Germany: Max Planck Digital Library. Retrieved December 21, 2017 from doi:10.17617/1.3.

Solomon, D.J., \& Björk, B.-C. (2012). “A study of OA journals using APCs.” J. Am. Soc. Inf. Sci. Technol. 2012, 63: 1485-1495. Retrieved December 21, 2017 from http://www.openaccesspublishing.org/ apc2/preprint.pdf.

Ubiquity Press (n.d.). Publishing. Retrieved Dec. 20, 2017 from https://www.ubiquitypress.com/ site/publish/

Universities UK (2017). Monitoring the transition to OA: December 2017. Retrieved Dec. 20, 2017 from http://www.universitiesuk.ac.uk/policy-and-analysis/reports/Pages/monitoring-transitionopen-access-2017.aspx

\section{ABSTRACTS}

The open access (OA) article processing charges (APC) project is a longitudinal study of the minority of fully OA journals (27\% in 2016) that have APCs. The global average APC shows little change; in USD, 906 in 2010, 964 in 2016, 974 in 2017. The average masks currency differences and the impact of a growing market; new APC journals often start with an APC of 0. Traditional 
commercial scholarly publishers are entering the OA market: the largest OA journal publishers' portfolios in 2017 were Springer, De Gruyter, Elsevier, and Wolters Kluwer Medknow. However, these are a small portion of OA journal publishing which is still marked by a very long tail and extensive involvement by very small, often university or society publishers. APC pricing shows a wide range and variability. The APC market can be described as volatile.

INDEX

Keywords: OA, APCs, economics

\section{AUTHOR}

\section{HEATHER MORRISON}

School of Information Studies, University of Ottawa, Canada Heather.Morrison@uottawa.ca

http://arts.uottawa.ca/sis/people/morrison-heather

(corresponding author) 